\title{
ASSOCIATION BETWEEN XRCC1 ARG399GLN AND P53 ARG72PRO POLYMORPHISMS AND THE RISK OF GASTRIC AND COLORECTAL CANCER IN TURKISH POPULATION
}

\author{
Ayse Basak ENGIN ${ }^{1}$, Bensu KARAHALIL ${ }^{1}$, Ali Esat KARAKAYA ${ }^{1}$, and Atilla ENGIN ${ }^{2}$ \\ Gazi University, Faculty of Pharmacy Department of Toxicologyl', Gazi University, Faculty of Medicine, \\ Department of General Surgery, Beşevler², Ankara, Turkey
}

Received in March 2011

CrossChecked in April 2011

Accepted in July 2011

\begin{abstract}
Gastric cancer is one of the most common cancers of the gastrointestinal system, and its overall five-year survival rate is still $15 \%$ to $20 \%$, as it can mostly be diagnosed at an advanced stage. On the other hand, although colorectal cancer has a rather good prognosis, mortality is one half that of the incidence.

As carcinogenesis is believed to involve reactive radicals that cause DNA adduct formation, impaired repair activity, and weakened tumour suppression, it would help to understand the role of the polymorphisms of nucleotide excision repair enzyme XRCC1 and of tumour suppressor gene $p 53$ in gastric and colorectal cancers. Our study included 94 gastric cancer patients, 96 colorectal cancer patients, and 108 cancer-free individuals as control with the aim to see if there was an association between XRCC1 Arg399Gln and $p 53$ Arg72Pro polymorphisms and cancer susceptibility. DNA was extracted from peripheral blood cells and genotypes were determined using the polymerase chain reaction-restriction fragment length polymorphism. Polymorphism $p 53$ Arg72Pro was not associated with either gastric or colorectal carcinoma, while XRCC1 Arg399Gln was not associated with the increased risk of colorectal cancer. However, XRCC1 homozygous Gln allele at codon 399 was associated with 2.54 times higher risk of gastric cancer.
\end{abstract}

KEY WORDS: DNA adduct, gene-gene interaction, PCR-RFLP

Genetic factors that alter repair of the damaged gastric and colon cell DNA leading to carcinoma have still been poorly understood. Accumulation of constantly generated reactive species during cellular metabolism and extracellular processes may contribute to carcinogenesis caused by oxidative DNA damage. p53, a tumour suppressor protein encoded in humans by the TP53 gene (1) regulates the cell cycle and preserves the stability of the human genome to prevent cancer initiation (2). It is estimated that almost $50 \%$ of cancer cases carry a mutation of the $p 53$ gene (3,
4). On the other hand, polymorphisms of genes involved in multiple steps of carcinogenesis may also account for genetic difference in susceptibility to gastric and colorectal carcinomas (5). Polymorphism in exon 4 , in the domain of transactivation of the p53 protein, results in an amino acid replacement from arginine (Arg) to proline (Pro). However, functional changes caused by this substitution are unknown. Inconsistent results have been found for the Pro variant allele of the $p 53$ gene as a risk factor of various cancers (5). The X-ray repair cross-complementing group 1 
(XRCC1) protein is involved in the repair of DNA base damage and single-strand DNA breaks. One of the common polymorphisms of the gene is at codon 399. This polymorphism leads to an amino acid replacement of Arg with glutamine (Gln) and can alter gene function. Previous studies have reported that the Gln allele at codon 399 is significantly associated with a higher level of DNA adducts $(6,7)$, increased sister chromatid exchange frequencies $(8,9)$, and increased sensitivity to ionising radiation (9). Therefore, the presence of homozygous Gln allele may alter cancer susceptibility and disease progression. In clinical studies, this polymorphism has been associated with the risk of several cancers and has also been used as a predictor of colorectal, bladder, and gastric cancers after chemotherapy (10-12). However, factors such as population stratification, ethnicity, and patient selection criteria may account for the discrepancies in findings. The aim of our study was to investigate the relation between $p 53$ Arg 72 Pro and XRCC1 Arg399Gln polymorphisms and susceptibility to gastric and colorectal carcinomas.

\section{MATERIALS AND METHODS}

\section{Patients and controls}

This prospective randomised study included 94 consecutive gastric cancer patients [mean age \pm standard error of mean (SEM): (60.3 \pm 1.4$)$ years; mean body mass index (BMI): (23.7 \pm 0.4$) \mathrm{kg} \mathrm{m}^{-2} ; 30$ women and $64 \mathrm{men}], 96$ consecutive colorectal cancer patients [mean age: (62.1 \pm 1.4$)$ years; BMI: $(25.7 \pm 0.4) \mathrm{kg} \mathrm{m}^{-2}$; 40 women and $56 \mathrm{men}]$, and 108 cancer-free patients [age: $(56.3 \pm 1.3)$ years; BMI: $(26.9 \pm 0.5) \mathrm{kg} \mathrm{m}^{-2}, 51$ women and $57 \mathrm{men}$ ] who were admitted to Gazi University, Faculty of Medicine, Department of General Surgery for surgical intervention. None of the patients had malignant or metabolic disorders, cardiopulmonary or metabolic risks that could be an obstacle for the surgery. The primary disease of the cancer patients was suitable for surgical intervention.

The study did not include patients with immune system disorders who could not receive surgical treatment or neoadjuvant chemotherapy due to the advanced stage of cancer, patients who had malnutrition, autoimmune diseases, systemic inflammatory response syndrome, intra-abdominal sepsis, chronic granulomatosis, collagen tissue or neurodegenerative diseases.

All participants' rights were protected and informed consents obtained according to the Helsinki Declaration. A local ethics committee approved the study protocol.

We isolated DNA from peripheral blood of each individual by extracting it with sodium perchlorate/ chloroform (13). p53 (GenBank ID: F261892S10) Arg72Pro and XRCCl (GenBank ID: L47234) Arg399Gln genotypes were determined using the polymerase chain reaction - restriction fragment length polymorphism (PCR-RFLP) according to modified

Table 1 Odds ratios for colorectal cancer according to the genotypes of $\mathrm{p} 53$ Arg72Pro and XRCC1Arg399Gln polymorphism

\begin{tabular}{|c|c|c|c|c|}
\hline \multirow{2}{*}{ Genotype } & Control Group & Colorectal Cancer Group & \multirow{2}{*}{ OR (95\% CI) } & \multirow{2}{*}{$\mathbf{p}$} \\
\hline & n $(\%)$ & n $(\%)$ & & \\
\hline \multicolumn{5}{|l|}{$p 53$} \\
\hline Arg / Arg & $52(48.1)$ & $50(52.1)$ & 1 & \\
\hline Arg / Pro & $42(38.9)$ & $41(42.7)$ & $1.015(0.569$ to 1.812$)$ & 0.959 \\
\hline \multirow{2}{*}{ Pro / Pro } & $14(13.0)$ & $5(5.2)$ & $0.371(0.125$ to 1.107$)$ & 0.068 \\
\hline & n (allele frequency) & n (allele frequency) & & \\
\hline Arg & $146(0.68)$ & $141(0.73)$ & & \\
\hline \multirow[t]{2}{*}{ Pro } & $70(0.32)$ & $51(0.27)$ & & \\
\hline & n (\%) & n (\%) & & \\
\hline \multicolumn{5}{|l|}{$X R C C 1$} \\
\hline Arg / Arg & $50(46.3)$ & $47(49.0)$ & 1 & \\
\hline Arg / Gln & $49(45.4)$ & $37(38.5)$ & $0.803(0.448$ to 1.440$)$ & 0.462 \\
\hline \multirow[t]{2}{*}{ Gln / Gln } & $9(8.3)$ & $12(12.5)$ & $1.418(0.548$ to 3.673$)$ & 0.470 \\
\hline & n (allele frequency) & n (allele frequency) & & \\
\hline Arg & $149(0.69)$ & $131(0.68)$ & & \\
\hline Gln & $67(0.31)$ & $61(0.32)$ & & \\
\hline
\end{tabular}

OR - odds ratio, CI - confidence interval 
protocols of Toruner(14) and Kocabas (15), respectively. For each individual, $50 \mathrm{ng}$ of DNA was used for the amplification reaction. PCR primers for $p 53 \mathrm{Arg} 72 \mathrm{Pro}$ were $\mathrm{F}$ 5'-TCCCCCCTTGCCGTCCCAA-3' and R 5'-CGTGCAAGTCACAGACTT-3' and for $\mathrm{XRCCl}$ Arg399Gln F 5'-CAGTGGTGCTAACCTAATC-3 and R 5'-AGTAGTCTGCTGGCTCTGG-3'. Briefly, for p53 Arg72Pro genotyping, $1.5 \mathrm{mmol} \mathrm{L}^{-1} \mathrm{MgCl}_{2}$, $0.2 \mathrm{mmol} \mathrm{L}^{-1}$ of each dNTP, $0.05 \mu \mathrm{mol} \mathrm{L}^{-1}$ of each primer, and $0.1 \mathrm{U} \mathrm{\mu L}^{-1}$ Taq polymerase were used to perform PCR. Thermal cycling conditions were $94{ }^{\circ} \mathrm{C}$ for 5 min, followed by 35 cycles of amplification (denaturation at $94{ }^{\circ} \mathrm{C}$ for $30 \mathrm{~s}$, annealing at $60^{\circ} \mathrm{C}$ for $30 \mathrm{~s}$, and extension at $72{ }^{\circ} \mathrm{C}$ for $30 \mathrm{~s}$ ) and a final elongation at $72{ }^{\circ} \mathrm{C}$ for $7 \mathrm{~min}$. PCR products were digested with Bsh 1236I (Fermentas Company, Lithuania) and separated by electrophoresis on $2 \%$ agarose gel (14). PCR tube for the genotyping of XRCCl Arg399Gln contained $2 \mathrm{mmol} \mathrm{L}^{-1} \mathrm{MgCl}_{2}$, $0.3 \mathrm{mmol} \mathrm{L}^{-1}$ of each dNTP, $0.4 \mu \mathrm{mol} \mathrm{L}^{-1}$ of each

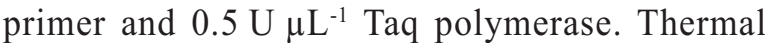
cycling conditions were $94{ }^{\circ} \mathrm{C}$ for $2 \mathrm{~min}$, followed by 35 cycles of amplification [denaturation at $94{ }^{\circ} \mathrm{C}(30 \mathrm{~s})$, annealing at $58^{\circ} \mathrm{C}(45 \mathrm{~s})$, and extension at $72{ }^{\circ} \mathrm{C}$ (45 s)], and a final elongation at $72{ }^{\circ} \mathrm{C}$ for $7 \mathrm{~min}$. PCR products were digested with MspI (Fermentas Company, Lithuania) and visualised on $2 \%$ agarose gel (15). Genotyping results for both polymorphisms were confirmed by DNA control sequences.

\section{Statistical analysis}

The results were expressed as mean \pm SEM, where appropriate. The deviation from the Hardy-Weinberg equilibrium was checked among cases and controls using the chi-square test with one degree of freedom. Odds ratios (ORs) with $95 \%$ confidence intervals (CIs) were determined with logistic regression models in order to evaluate the association between gastric or colorectal cancer and p53 Arg72Pro and XRCC1 Arg399Gln polymorphisms. Data were analysed using the statistical package SPSS, version 13.0 (SPSS Inc., Chicago, IL, USA).

\section{RESULTS}

Gastric cancer patients, colorectal cancer patients, and cancer-free patients were genotyped in order to determine $p 53$ Arg72Pro and XRCC1 Arg399Gln polymorphisms. None of the genotype distributions deviated from the Hardy-Weinberg equilibrium. Neither of the polymorphisms was associated with colorectal cancer (Table 1). However, the risk of gastric cancer was found to be 2.54 times higher in the homozygous carriers of variant XRCC1 Arg399Gln allele (Table 2; $\mathrm{p}<0.05$ ). Evaluation by dominant model and model of heterozygote advantage for both $p 53$ Arg72Pro and XRCC1 Arg399Gln polymorphisms did not reach

Table 2 Odds ratios for gastric cancer according to the genotypes of $\mathrm{p} 53$ Arg 72 Pro and XRCC1Arg399Gln polymorphism

\begin{tabular}{|c|c|c|c|c|}
\hline \multirow{2}{*}{ Genotype } & Control Group & Gastric Cancer Group & \multirow{2}{*}{ OR (95 \% CI) } & \multirow{2}{*}{$\mathbf{p}$} \\
\hline & n $(\%)$ & $\mathrm{n}(\%)$ & & \\
\hline \multicolumn{5}{|l|}{ p53 } \\
\hline Arg / Arg & $52(48.1)$ & $40(42.6)$ & 1 & \\
\hline Arg / Pro & $42(38.9)$ & $41(43.6)$ & $1.269(0.699$ to 2.303$)$ & 0.433 \\
\hline \multirow[t]{2}{*}{ Pro / Pro } & $14(13.0)$ & $13(13.8)$ & $1.207(0.511$ to 2.853$)$ & 0.668 \\
\hline & n (allele frequency) & n (allele frequency) & & \\
\hline Arg & $146(0.68)$ & $121(0.64)$ & & \\
\hline \multirow[t]{2}{*}{ Pro } & $70(0.32)$ & $67(0.36)$ & & \\
\hline & n (\%) & n (\%) & & \\
\hline \multicolumn{5}{|l|}{ XRCC1 } \\
\hline Arg / Arg & $50(46.3)$ & $35(37.2)$ & 1 & \\
\hline Arg / Gln & $49(45.4)$ & $43(45.7)$ & $1.254(0.691$ to 2.273$)$ & 0.456 \\
\hline \multirow[t]{2}{*}{ Gln / Gln } & $9(8.3)$ & $16(17.0)$ & $2.540(1.008$ to 6.397$)$ & $0.044 *$ \\
\hline & n (allele frequency) & n (allele frequency) & & \\
\hline Arg & $149(0.69)$ & $113(0.60)$ & & \\
\hline Gln & $67(0.31)$ & $75(0.40)$ & & \\
\hline
\end{tabular}

OR - odds ratio, CI - confidence interval, * $p<0.05$, considered as statistically significant. 
statistical significance in either colorectal or gastric cancer (all; $\mathrm{p}>0.05$ ). On the other hand, the combination of the mutant genotypes of $p 53 \mathrm{Arg} 72$ Pro and $\mathrm{XRCCl}$ Arg399Gln did not increase the risk of colorectal or gastric cancer (Tables 3 and 4; $p>0.05$ ). Gastric cancer risk was 1.91 times higher in men than in women [OR at $95 \% \mathrm{CI}: 1.909$ (1.074 to 3.393 ), $\mathrm{p}<0.027]$. However, there was no association between either of the polymorphisms and gastric or colorectal cancer when evaluated separately for women and men $(\mathrm{p}>0.05)$.

\section{DISCUSSION}

Eariler studies on the association between p53 Arg72Pro and XRCC1 Arg399Gln polymorphisms and gastric and colorectal carcinomas revealed inconsistent results that might be attributed to a number of genetic and ethnic factors (16-27). The p53 tumour suppressor protein is essential in cell cycle control and maintenance of genomic stability (28). Yi et al. (5) propose that independent of transcription, p53 favours apoptosis in cells with DNA damage (5). The loss of p53 function is one of the key factors in cancer development (29). The Arg/Pro polymorphism at codon 72 is one of the ten polymorphisms that have been detected in human p53 so far (30). Sreeja et al. (31) have shown that the Pro allele at codon 72 may alter the enzyme activity of $\mathrm{p} 53$. The Pro allele seems to favour p53 binding to p73, a 553 homologue and transcription factor of some $p 53$ target genes, which may lead to alterations in the activation of some p53-interacting genes (32). Regarding to these assumptions, Van Oijen et al. (29) have found both the mutation and retention of the Arg allele. Bae et al. (33) have shown that a difference at a single codon of the $p 53$ gene can alter the protein. Moreover, the distribution of p53 codon 72 polymorphism changes with ethnicity. Studies from Switzerland and the USA showed that almost $50 \%$ of the population had the Arg/Arg genotype of $p 53$ at codon $72(16,17)$. However, two separate studies from China established different genotype distributions for the $p 53$ Arg 72 Pro polymorphism $(18,19)$. According to Almeida et al. (34), genotype distribution in a Brazilian population was $60 \%$ for homozygous $p 53$ Arg/Arg, $28.2 \%$ for heterozygous $p 53 \mathrm{Arg} / \mathrm{Pro}$, and $11.8 \%$ for homozygous $p 53$ Pro/Pro. Compared to

Table 3 Odds ratios for colorectal cancer according to the combination of genotypes of $\mathrm{p} 53$ Arg 72 Pro and XRCC1Arg399Gln polymorphisms

\begin{tabular}{lccccc}
\hline $\begin{array}{l}\boldsymbol{p 5 3} \\
\text { Genotype }\end{array}$ & $\begin{array}{c}\text { XRCC1 } \\
\text { Genotype }\end{array}$ & $\begin{array}{c}\text { Control Group } \\
\mathbf{n}(\mathbf{\%})\end{array}$ & $\begin{array}{c}\text { Colorectal Cancer Group } \\
\mathbf{n}(\mathbf{\%})\end{array}$ & $\begin{array}{c}\text { OR } \\
\text { (95 \% CI) }\end{array}$ & p \\
\hline Arg / Arg & Arg / Arg & $25(23.1)$ & $27(28.1)$ & $0.789(0.362$ to 1.717$)$ & 0.550 \\
\hline Arg / Arg & $\begin{array}{l}\text { Arg / Gln } \\
\text { Gln / Gln }\end{array}$ & $27(25.0)$ & $23(24.0)$ & $0.741(0.332$ to 1.650$)$ & 0.462 \\
\hline $\begin{array}{l}\text { Arg / Pro } \\
\text { Pro / Pro }\end{array}$ & Arg / Arg & $25(23.1)$ & $20(20.8)$ & $0.777(0.366$ to 1.650$)$ & 0.510 \\
\hline $\begin{array}{l}\text { Arg / Pro } \\
\text { Pro / Pro }\end{array}$ & $\begin{array}{l}\text { Arg / Gln } \\
\text { Gln / Gln }\end{array}$ & $31(28.7)$ & $26(27.1)$ & & \\
\hline
\end{tabular}

OR; odds ratio, CI; confidence interval

Table 4 Odds ratios for gastric cancer according to the combination of genotypes of p53 Arg72Pro and XRCC1Arg399Gln polymorphisms

\begin{tabular}{lccccc}
\hline $\begin{array}{l}\boldsymbol{p 5 3} \\
\text { Genotype }\end{array}$ & $\begin{array}{c}\text { XRCC1 } \\
\text { Genotype }\end{array}$ & $\begin{array}{c}\text { Control Group } \\
\mathbf{n}(\mathbf{\%})\end{array}$ & $\begin{array}{c}\text { Gastric Cancer Group } \\
\mathbf{n}(\mathbf{\%})\end{array}$ & $\begin{array}{c}\text { OR } \\
\text { (95 \% CI) }\end{array}$ & p \\
\hline Arg / Arg & Arg / Arg & $25(23.1)$ & $14(14.9)$ & 1 & 0.208 \\
\hline Arg / Arg & $\begin{array}{l}\text { Arg / Gln } \\
\text { Gln / Gln }\end{array}$ & $27(25.0)$ & $26(27.7)$ & $1.720(0.737$ to 4.013) & 0.363 \\
\hline $\begin{array}{l}\text { Arg / Pro } \\
\text { Pro / Pro }\end{array}$ & Arg / Arg & $25(23.1)$ & $21(22.3)$ & $1.500(0.626$ to 3.596) & 0.122 \\
\hline $\begin{array}{l}\text { Arg / Pro } \\
\text { Pro / Pro }\end{array}$ & $\begin{array}{l}\text { Arg / Gln } \\
\text { Gln / Gln }\end{array}$ & $31(28.7)$ & $33(35.1)$ & $1.901(0.839$ to 4.305) & 0.122 \\
\hline
\end{tabular}

OR - odds ratio, CI - confidence interval 
literature data, Turkish population has a similar genotypic distribution as Caucasians.

In our study, we have not found any association between $p 53$ Arg72Pro polymorphism and increased risk of either gastric or colorectal cancer. In contrast, $\mathrm{Xi}$ et al. (35) found a relation between the increased risk of gastric carcinoma and $p 53$ Arg72Pro polymorphism and said that bad prognosis was associated with $p 53$ mutation. In a Japanese study, Hiyama et al. (36) found similar allele frequencies in both control and gastric cancer patients. Similarly, an Argentine study (20) found that individuals with the Pro/Pro genotype had an increased risk of colorectal cancer. Evaluating 1000 incident gastric cancer patients and 1300 controls, Liu et al. (37) found no independent effects of $p 53 \mathrm{Arg} 72$ Pro on gastric cancer risk. A study from the USA (38) found no association between colorectal cancer and p53 Arg72Pro polymorphism, but Jones et al. (39) identified $p 53$ Pro allele at codon 72 as a risk factor for colorectal cancer in combination with environmental factors. Casecontrol studies in Japan and Turkey failed to find a relation between the $p 53$ polymorphism and colorectal cancer $(40,41)$.

$\mathrm{XRCC} 1$ acts as a central scaffolding protein and plays a crucial role in the removal of endogenous and exogenous DNA damage $(6,7)$. Our study has shown that the distribution of the $X R C C 1$ homozygous mutant genotype in Turkish population is between Asian and Caucasian populations, while heterozygous $\mathrm{Arg} / \mathrm{Gln}$ allele distribution in XRCC1 codon 399 was similar in both Asian and Caucasian populations $(21,23,24)$. Surprisingly, we have found a different frequency of homozygous mutant genotype of XRCCl than the previous study by Kocabas et al. (15). This contradiction might be attributed to different ethnic groups and divergent genetic pool in Turkey.

In our study, there was no association between the increased risk of colorectal carcinoma and $\mathrm{XRCCl}$ Gln allele at codon 399. This is in agreement with an Italian (25) and an English study (26). In a study with 207 cancer patients and 621 controls, Jin et al. (42) identified the $\mathrm{XRCCl}$ Gln allele at codon 399 as an independent factor for colorectal cancer.

Findings on the association between $\mathrm{XRCCl}$ Arg399Gln polymorphism and gastric cancer are also controversial. Studies by Lee et al. (24) and Geng et al. (43) in Asian populations, and studies by Huang et al. (22) in Polish and by Duarte et al. (21) in Brazillian population found no association while, Capella et al. (27) and Ratnasinghe et al. (23) established a relationship between the $X R C C 1$ Arg allele at codon 399 and gastric cancer originating from different segments of the stomach. We too have found that individuals carrying homozygous Gln allele have a 2.54 times higher risk of gastric cancer.

In contrast, the combination of the mutant genotypes of $p 53$ Arg72Pro and XRCC1 Arg399Gln did not alter the risk of either colorectal or gastric cancer. This suggests that the homozygous mutant alleles in these two unrelated genes do not affect each other in such way as to increase the risk of colorectal or gastric cancers.

Our study has also established a two times higher gastric cancer risk in men than in women, which is in accordance with global data (44).

However, there are several limitations to our study. Being hospital-based and case-control, it may be subject to selection bias. However, this bias is of no great concern, as our study focuses on a genotypedriven interaction rather than an environment-driven one. Our results are based on a limited number of single-nucleotide polymorphisms and additional, larger-scaled studies are needed to determine the interaction between genetic and environmental factors and the risk of gastric and colorectal carcinomas.

Controversial as they may be, however, our findings call for further evaluation of XRCC1 polymorphism as a risk factor for gastric cancer.

\section{Acknowledgement}

This study was supported by the Scientific and Technological Research Council of Turkey [Grant No:107S363].

\section{Conflict of interest statement}

All authors declare that they have no direct financial interest in the subject matter or materials discussed that could inappropriately influence the manuscript.

\section{REFERENCES}

1. McBride OW, Merry D, Givol D. The gene for human p53 cellular tumor antigen is located on chromosome 17 short arm (17p13). Proc Natl Acad Sci USA 1986;83:130-4.

2. Strachan T, Read AP. Human molecular genetics. $2^{\text {nd }}$ edition. New York (NY): Wiley-Liss; 1999.

3. Lane DP. Cancer. p53 guardian of the genome. Nature 1992:358:15-6. 
4. Brachmann RK. p53 mutants: the achilles' heel of human cancers? Cell Cycle 2004;3:1030-4.

5. Yi SY, Lee WJ. A p53 genetic polymorphism of gastric cancer: difference between early gastric cancer and advanced gastric cancer. World J Gastroenterol 2006;12:6536-9.

6. Lunn RM, Langlois RG, Hsieh LL, Thompson CL, Bell DA. XRCC1 polymorphisms: effects on aflatoxin B1-DNA adducts and glycophorin Avariant frequency. Cancer Res 1999;59:2557-61.

7. Matullo G, Guarrera S, Carturan S, Peluso M, Malaveille C, Davico L, Piazza A, Vineis P. DNA repair gene polymorphisms, bulky DNA adducts in white blood cells and bladder cancer in a case-control study. Int J Cancer 2001;92:562-7.

8. Abdel-Rahman SZ, Soliman AS, Bondy ML, Omar S, ElBadawy SA, Khaled HM, Seifeldin IA, Levin B. Inheritance of the 194Trp and the 399Gln variant alleles of the DNA repair gene XRCC1 are associated with increased risk of early-onset colorectal carcinoma in Egypt. Cancer Lett 2000;159:79-86.

9. Duell EJ, Wiencke JK, Cheng TJ, Varkonyi A, Zuo ZF, Ashok TD, Mark EJ, Wain JC, Christiani DC, Kelsey KT. Polymorphisms in the DNA repair genes XRCC1 and ERCC2 and biomarkers of DNA damage in human blood mononuclear cells. Carcinogenesis 2000;21:965-71.

10. Moreno V, Gemignani F, Landi S, Gioia-Patricola L, Chabrier A, Blanco I, González S, Guino E, Capellà G, Canzian F. Polymorphisms in genes of nucleotide and base excision repair: risk and prognosis of colorectal cancer. Clin Cancer Res 2006;12:2101-8.

11. Sakano S, Wada T, Matsumoto H, Sugiyama S, Inoue R, Eguchi S, Ito H, Ohmi C, Matsuyama H, Naito K. Single nucleotide polymorphisms in DNA repair genes might be prognostic factors in muscle-invasive bladder cancer patients treated with chemoradiotherapy. Br J Cancer 2006;95:56170.

12. Ruzzo A, Graziano F, Kawakami K, Watanabe G, Santini D, Catalano V, Bisonni R, Canestrari E, Ficarelli R, Menichetti ET, Mari D, Testa E, Silva R, Vincenzi B, Giordani P, Cascinu S, Giustini L, Tonini G, Magnani M. Pharmacogenetic profiling and clinical outcome of patients with advanced gastric cancer treated with palliative chemotherapy. J Clin Oncol 2006;24:1883-91.

13. Karahalil B, Kocabaş NA, Ozçelik T. DNA repair gene polymorphisms and bladder cancer susceptibility in a Turkish population. Anticancer Res 2006;26:4955-8.

14. Toruner GA, Ucar A, Tez M, Cetinkaya M, Ozen H, Ozçelik T. p53 codon 72 polymorphism in bladder cancer-no evidence of association with increased risk or invasiveness. Urol Res 2001;29:393-5.

15. Kocabaş NA, Karahalil B. XRCC1 Arg399Gln genetic polymorphism in a Turkish population. Int J Toxicol 2006;25:419-22.

16. Ørsted DD, Bojesen SE, Tybjærg-Hansen A, Nordestgaard BG. Tumor suppressor p53 Arg72Pro polymorphism and longevity, cancer survival, and risk of cancer in the general population. JEM 2007;204:1295-301.

17. Madeleine MM, Shera K, Schwartz SM, Daling JR, Galloway DA, Wipf GC, Carter JJ, McKnight B, McDougall JK. The p53 Arg72Pro polymorphism, human papillomavirus, and invasive squamous cell cervical cancer. Cancer Epidemiol Biomarkers Prev 2000;9:225-7.
18. Ma H, Hu Z, Zhai X, Wang S, Wang X, Qin J, Chen W, Jin G, Liu J, Gao J, Wang X, Wei Q, Shen H. Joint effects of single nucleotide polymorphisms in P53BP1 and p53 on breast cancer risk in a Chinese population. Carcinogenesis 2006;27:766-71.

19. Zhu ZZ, Cong WM, Liu SF, Dong H, Zhu GS, Wu MC. Homozygosity for Pro of p53 Arg72Pro as a potential risk factor for hepatocellular carcinoma in Chinese population. World J Gastroenterol 2005;11:289-92.

20. Vidaurreta M, Maestro ML, Sanz-Casla MT, Rafael S, Veganzones S, de la Orden V, Cerdán J, Arroyo M, Torres A. Colorectal carcinoma prognosis can be predicted by alterations in gene p53 exons 5 and 8 . Int J Colorectal Dis 2008;23:581-6.

21. Duarte MC, Colombo J, Rossit AR, Caetano A, Borim AA, Wornrath D, Silva AE. Polymorphisms of DNA repair genes $\mathrm{XRCC} 1$ and $\mathrm{XRCC} 3$, interaction with environmental exposure and risk of chronic gastritis and gastric cancer. World J Gastroenterol 2005;11:6593-600.

22. Huang SP, Huang CY, Wang JS, Liu CC, Pu YS, Yu HJ, Yu CC, Wu TT, Huang CH, Wu WJ, Chou YH, Wu MT. Prognostic significance of $\mathrm{p} 53$ and $\mathrm{X}$-ray repair crosscomplementing group 1 polymorphisms on prostate-specific antigen recurrence in prostate cancer post radical prostatectomy. Clin Cancer Res 2007;15:13:6632-8.

23. Ratnasinghe LD, Abnet C, Qiao YL, Modali R, StolzenbergSolomon R, Dong ZW, Dawsey SM, Mark SD, Taylor PR. Polymorphisms of XRCC1 and risk of esophageal and gastric cardia cancer. Cancer Lett 2004;216:157-64.

24. Lee SG, Kim B, Choi J, Kim C, Lee I, Song K. Genetic polymorphisms of XRCC1 and risk of gastric cancer. Cancer Lett 2002;187:53-60.

25. Improta G, Sgambato A, Bianchino G, Zupa A, Grieco V, La Torre G, Traficante A, Cittadini A. Polymorphisms of the DNA repair genes XRCC1 and XRCC3 and risk of lung and colorectal cancer: a case-control study in a Southern Italian population. Anticancer Res 2008;28:2941-6.

26. Mort R, Mo L, McEwan C, Melton DW. Lack of involvement of nucleotide excision repair gene polymorphisms in colorectal cancer. Br J Cancer 2003;89:333-7.

27. Capellá G, Pera G, Sala N, Agudo A, Rico F, Del Giudicce G, Plebani M, Palli D, Boeing H, Bueno-de-Mesquita HB, Carneiro F, Berrino F, Vineis P, Tumino R, Panico S, Berglund G, Simán H, Nyrén O, Hallmans G, Martinez C, Dorronsoro M, Barricarte A, Navarro C, Quirós JR, Allen N, Key T, Bingham S, Caldas C, Linseisen J, Nagel G, Overvad K, Tjonneland A, Boshuizen HC, Peeters PH, Numans ME, Clavel-Chapelon F, Trichopoulou A, Lund E, Jenab M, Kaaks R, Riboli E, González CA. DNA repair polymorphisms and the risk of stomach adenocarcinoma and severe chronic gastritis in the EPIC-EURGAST study. Int J Epidemiol 2008;37:1316-25.

28. Marin MC, Jost CA, Brooks LA, Irwin MS, O’Nions J, Tidy JA, James N, McGregor JM, Harwood CA, Yulug IG, Vousden KH, Allday MJ, Gusterson B, Ikawa S, Hinds PW, Crook T, Kaelin WG Jr. A common polymorphism acts as an intragenic modifier of mutant p53 behaviour. Nat Genet 2000;25:47-54.

29. van Oijen MG, Slootweg PJ. Gain-of-function mutation in the tumor suppressor gene p53. Clin Cancer Res 2000;6:213845. 
30. Hoe YJ, Cho HM, Chin HM, Kim W, Jeon HM. Gastric cancer susceptibility in the p53 codon 72 polymorphism. J Korean Surg Soc 2005;69:24-30.

31. Sreeja L, Syamala V, Raveendran PB, Santhi S, Madhavan J, Ankathil R. p53 Arg72Pro polymorphism predicts survival outcome in lung cancer patients in Indian population. Cancer Invest 2008;26:41-6.

32. Pérez LO, Abba MC, Dulout FN, Golijow CD. Evaluation of p53 codon 72polymorphism in adenocarcinomas of the colon and rectum in La Plata, Argentina. World J Gastroenterol 2006;12:1426-9.

33. Bae DH, Kim JS, Choi SD, Sunwoo JG, Nam KH, Kim CJ. Human papillomavirus infection and polymorphism of p53 codon 72 in the uterine cervical neoplasia. Korean J Gynecol Oncol Colposc 2003;14:281-9.

34. Almeida PS, Manoel WJ, Reis AA, Silva ER, Martins E, Paiva MV, Fraga AC Jr, Saddi VA. TP53 codon 72 polymorphism in adult soft tissue sarcomas. Genet Mol Res 2008;7:1344-52

35. Xi YG, Ding KY, Su XL, Chen DF, You WC, Shen Y, Ke Y p53 polymorphism and p21WAF1/CIP1 haplotype in the intestinal gastric cancer and the precancerous lesions. Carcinogenesis 2004;25:2201-6.

36. Hiyama T, Tanaka S, Kitadai Y, Ito M, Sumii M, Yoshihara M, Shimamoto F, Haruma K, Chayama K. p53 Codon 72 polymorphism in gastric cancer susceptibility in patients with Helicobacter pylori-associated chronic gastritis. Int J Cancer 2002;100:304-8

37. Liu JN, Zhang XM, Guo YL, Sun T, Lin DX, Wen T. [Genetic polymorphism in MDM2 is associated with susceptibility to colorectal cancer in a Chinese population, in Chinese]. Zhonghua Zhong Liu Za Zhi 2008;30:335-8.

38. Koushik A, Tranah GJ, Ma J, Stampfer MJ, Sesso HD, Fuchs CS, Giovannucci EL, Hunter DJ. p53 Arg72Pro polymorphism and risk of colorectal adenoma and cancer. Int J Cancer 2006;119:1863-8.

39. Jones JS, Chi X, Gu X, Lynch PM, Amos CI, Frazier ML. p53 polymorphism and age of onset of hereditary nonpolyposis colorectal cancer in a Caucasian population. Clin Cancer Res 2004; 10:5845-9.

40. Murata M, Tagawa M, Kimura M, Kimura H, Watanabe S, Saisho H. Analysis of a germ line polymorphism of the p53 gene in lung cancer patients; discrete results with smoking history. Carcinogenesis 1996;17:261-4.

41. Sayhan N, Yazici H, Budak M, Bitisik O, Dalay N. p53 codon 72 genotypes in colon cancer. Association with human papillomavirus infection. Res Commun Mol Pathol Pharmacol 2001;109:25-34

42. Jin MJ, Chen K, Zhang Y, Zhang W, Liu B, Zhang YJ. [Correlations of single nucleotide polymorphisms of DNA repair gene XRCC1 to risk of colorectal cancer, in Chinese]. Ai Zheng 2007;26:274-9.

43. Geng J, Zhang YW, Huang GC, Chen LB. XRCC1 genetic polymorphism Arg399Gln and gastric cancer risk: A metaanalysis. World J Gastroenterol 2008;14:6733-7.

44. Parkin DM, Bray F, Ferlay J, Pisani P. Global Cancer Statistics, 2002. CA Cancer J Clin 2005;55:74-108. 


\section{Sažetak \\ POVEZANOST IZMEĐU POLIMORFIZAMA XRCC1 ARG399GLN I P53 ARG72PRO S RIZIKOM OD RAKA ŽELUCA I DEBELOGA CRIJEVA U TURSKOJ POPULACIJI}

Rak želuca najčešći je oblik karcinoma probavnoga sustava, a ukupno mu je preživljenje i dalje $15 \%$ do $20 \%$, budući da se većinom dijagnosticira u poodmakloj fazi razvoja. S druge pak strane, premda rak debeloga crijeva ima prilično dobru prognozu, smrtnost je i dalje $50 \%$.

Vjeruje se da je nastanak karcinoma povezan s reaktivnim radikalima koji uzrokuju stvaranje DNA-adukata, onemogućavaju popravak DNA te slabe supresiju tumora. Stoga bi bilo korisno razumjeti ulogu polimorfizama gena za enzim XRCC1 koji sudjeluje u popravku isjecanjem nukleotida i tumor-supresorskoga gena $p 53$ u nastanku raka želuca i debeloga crijeva. Naše je ispitivanje obuhvatilo 94 bolesnika s rakom želuca, 96 bolesnika s rakom debeloga crijeva te 108 kontrolnhih ispitanika (koji nisu oboljeli od bilo kojeg oblika raka) s ciljem da se utvrdi povezanost između polimorfizama XRCC1 Arg399Gln i p53 Arg72Pro i sklonosti nastanku raka. DNA je dobiven iz stanica periferne krvi, a genotip utvrđen s pomoću metode lančane reakcije polimerazom - polimorfizma restrikcijskih fragmenata na osnovi dužine (PCRRLFP). Polimorfizam $p 53$ Arg72Pro nije se pokazao povezanim s povećanim rizikom od raka želuca ili debeloga crijeva niti je XRCC1 Arg399Gln bio povezan s povećanim rizikom od raka debeloga crijeva, ali je zato rizik od raka želuca u homozigotnih nositelja ovoga polimorfizma bio 2,54 puta veći.

KLJUČNE RIJEČI: DNA-adukt, interakcija između gena, PCR-RFLP

\section{CORRESPONDING AUTHOR:}

Ayse Basak Engin M.Sc., Ph.D.

Gazi University, Faculty of Pharmacy

Department of Toxicology

TR 06330 Hipodrom, Ankara, Turkey

E-mail:abengin@gmail.com 